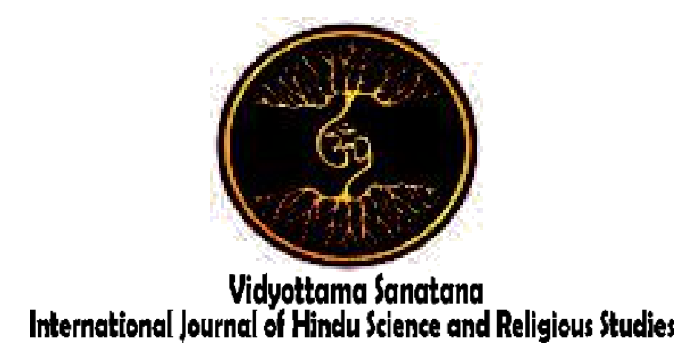

Vol. 2 No. 2 October 2018

\title{
Pancasila Values In Tradition On The Bali Hindu Community Reviewed From Bali Adat Law And Hindu's Law
}

\author{
By: \\ Arinita Sandria \\ Universitas Komputer Indonesia, Bandung \\ E-mail: arinita.sandria@email.unikom.ac.id
}

Received: August 5, 2018

Accepted: September 13, 2018

Published: October 31, 2018

\begin{abstract}
Adat law is an unwritten law that applies to a particular society. One of adat law that is still valid in Indonesia is Balinese Adat Law which is strongly influenced by Hindu religious law. Adat Law Society of Bali has many traditions related to various religious activities, one of which is ngayah. The development of the times influenced the existence of the ngayah tradition in the Balinese Hindu community. Many Balinese Hindus, especially those outside Bali, currently do not carry out ngayah. This will certainly have a negative impact on the continuation of the ngayah tradition. This is what prompted researchers to conduct research on cultivation in the Balinese Hindu community. The problems raised by researchers in this regard are: 1) How the implementation of Pancasila values contained in ngayah in the Balinese Hindu community; and 2) How is the application of sanctions for Balinese Hindus who do not implement ngayah in terms of Adat Law and Hindu Law

This research was carried out in a descriptive analytical way, which provides a careful description of the facts that are related to the research. This study uses a juridical empirical approach. This research was conducted in two stages, namely library research (library research) and field data. Data collection techniques in this study were conducted in two ways, namely doku men and interview studies Data analysis was performed using qualitative juridical analysis methods. The location of the study to obtain data in this writing is the library and institutions related to research. The conclusions that can be drawn are: 1) Ngayah as a tradition in the Balinese Hindu community is very full of the values of Pancasila; and 2) Application of sanctions for Balinese Hindus who do not carry out ngayah in terms of Adat Law and Religious Law in general are customary sanctions in the form of danda
\end{abstract}

Keywords: Ngayah, Balinese Adat Law, Hindu Law 


\section{Introduction}

Indonesia is a legal state (rechstaat), this is confirmed in Pasal 1 ayat (3) of the Undang-Undang Dasar 1945. A legal state means that all government actions must be based on law. The source of all sources of law in Indonesia is Pancasila, therefore there cannot be any legislation that is contrary to Pancasila. Pancasila is also an ideology of the Indonesian nation which means there can be no other ideologies in Indonesia, be it communism, liberalism or ideology based on a particular religion because Indonesia is a religious and not a religious state. The religious state recognizes that there are many religions in the country, while the religious state is a country that only recognizes the existence of 1 (one) religion in its country.

Von Savigny explained that every nation has its own soul called volkgeist (soul of the people or soul of the nation). Pancasila is the soul of the Indonesian people that was born along with the birth of the Indonesian nation in the Majapahit and Srivijaya days, long before the formation of the Unitary Republic of Indonesia (NKRI). Pancasila as the soul of the nation means that Pancasila animates every action of the Indonesian people. This is reflected in the attitude of the Indonesian people.

The Indonesian nation is a nation that is very pluralistic with a variety of tribes, religions, ethnicities and others. All Indonesian citizens must respect and respect this diversity. This is confirmed in Pasal 36A of Undang-Undang Dasar 1945 which states that: "The symbol of the state is the Garuda Pancasila with the motto of Unity in Diversity."

Bhinneka Tunggal Ika Tan Hana Dharma Mangrwa is found in the Sutasoma Book written by Empu Tantular, which means even though it is different but dharma (truth) is one. This motto is the forerunner of tolerance among Indonesians who are very diverse. The Indonesian nation is a nation that consists of many tribes and one of the tribes that is still highly recognized is the
Balinese tribe whose people are still subject to the Adat Law of Bali.

Adat Law is a law that grows in Indonesian society which is in the form of legal norms that arise and grow inside and are caused by the association of human life ${ }^{1}$. Balinese Adat Law is a complex of norms, both in its written and unwritten forms, containing commands, permissions and prohibitions, which govern the lives of Balinese people concerning the relationship between fellow human beings, the relationship between humans and nature and the relationship between humans and God. ${ }^{2}$

Adat is a community behavior that always happens in people's daily lives. ${ }^{3}$ Adat is a community habit that is steady (carried out continuously) and maintained by its supporters. Every nation or society has its own cultures. This difference shows that every society has its own characteristics as the identity of the nation in question. This characteristic is referred to as the genius logic, local prudencia or local wisdom. Adat is often referred to as tradition. The tradition is etymologically derived from Latin, tradere which means hereditary.

The Balinese Hindu community is still very strong in holding tradition. All activities carried out by the Balinese Hindu community in general are a tradition that comes from ancestors, one of which is ngayah. Ngayah is a social obligation of the Balinese Hindu community which is carried

${ }^{1}$ Djaren Saragih, Pengantar Hukum Adat Indonesia Edisi III, Bandung : Tarsito, Bandung, 1996, P.6.

22 Wayan P. Windia dan Ketut Sudantra, Pengantar Hukum Adat Bali, Denpasar: Swasta Nulus Bekerja sama dengan Bali Shanti Pusat Pelayanan Konsultasi Adat dan Budaya Bali LPPM Unud dan Puslit Hukum Adat LPPM Unud, 2016, P. 8.

3 Tolib Setiady, Intisari Hukum Adat Indonesia - Dalam Kajian Kepustakaan, Bandung : Alfabeta,2015, P. 5. 
out jointly with a sincere, sincere heart, both in the banjar and in the holy place, which is thought to have existed since the days of the Balinese kings. Ngayah also means doing a job without getting a salary. Understanding etymologically comes from the word father, related to Balinese purusaism, patrilineal society. The word father then developed into ayahan which refers to the village land with various obligations which are a consequence of the people who inhabit the land.

The Balinese Hindu community is a society that is strongly influenced by the values in Hinduism, therefore it is also in harmony with one of the principles in Hinduism. The principle is that all activities carried out by Hindus are based on sincere and sincere souls. All activities carried out by Hindus are an offering to Ista Dewata (Sang Hyang Widhi Wasa which is realized both in Nirguna Brahman and in Saguna Brahman). This principle is regulated in Bhagawadgita II.47, namely: "Karmany evadhikaras te ma phalesu kadacana ma karma phala hetur bhur ma te sanggostava akarmani. (Only doing duty is not the result of that action (you think), never reward is your motive for working, do not also work (nirkarma) because it is merely narrow".

The tradition of ngayah in the Balinese Hindu community is slowly becoming obsolete. Some Balinese Hindus are no longer carrying out ngayah for a variety of reasons, mainly due to their busy work, especially for Balinese Hindus who do not live in Bali. Whereas in the tradition ngayah contained Pancasila values which are the source of all sources of law.

\section{RESEARCH METHODS}

This study uses an empirical juridical approach. This approach aims to understand that law is not merely a set of normative laws and regulations but is also understood as a pattern of community behavior in the life of the community and always interacting with various aspects of society, such as economic, social and cultural aspects and others other. ${ }^{4}$ Based on the objectives to be achieved, this study was carried out in a descriptive analytical manner, which is intended to provide as accurate data as possible about humans, other conditions or symptoms. ${ }^{5}$

This research was conducted in two stages, namely:

\section{Library Research (Library Research)}

This step is carried out to obtain primary legal material in the form of binding legal materials, such as legislation, such as, secondary legal materials which include legal and non-legal references in the form of research results, papers and tertiary legal materials in the form of various articles from mass media, encyclopedias, dictionaries and others.

2. Field Research

Field research is intended to support library data. Field research is carried out by conducting interviews with various competent parties related to this research, including:

a. Ida Bagus Parwatha, traditional leader in banjar Pekandelan, desa of Sanur Kaja, kecamatan Denpasar Selatan, kotamadya Denpasar, province of Bali.

b. Matra Kumara, a traditional leader in desa Padangbai, kecamatan Manggis, kabupaten Karangasem, Bali province.

c. Made Sutama, traditional leader in desa Ulakan, kecamatan Manggis, kabupaten Karangasem, Bali province.

d. Wayan Sutawa, traditional leader in desa Simpang Jeruk, kecamapatan Lingga, Lampung province.

\section{Results And Discussion}

3.1 Implementation of the values of Pancasila contained in Ngayah in the Balinese Hindu Community

${ }^{4}$ Ronny Hanitijo Soemitro, Metodologi Penelitian Hukum dan Jurimetri, Ghalia Indonesia, Jakarta, Cetakan kelima, 1994, P. 34.

${ }^{5}$ Ibid, hlm. 20. 
Ngayah contains values in Pancasila which are reflected in the 45 points of Pancasila in accordance with the Tap MPR No.1 / MPR / 2003. It is in line with the first principle of Pancasila, namely the Godhead of the One God, where the first point is that the Indonesian people express their belief and piety towards God Almighty. Ngayah is a service to God Almighty. Hindus generally carry out ngayah related to the holding of religious ceremonies such as Nyepi, Galungan, Kuningan and others. Ngayah also reflects respect for respecting and cooperating between religious adherents with different adherents of belief in God Almighty.

Ngayah is in accordance with the second principle of Pancasila, which is just and civilized humanity. One of the points of the second principle is to recognize equality, equality of rights and basic obligations of every human being, regardless of ethnicity, ancestry, religion, belief, gender, social position, skin color and so on. The Balinese Hindu community with its caste is known as a society with a closed social stratification system, in which one's status is determined due to offspring and one cannot simply switch status. However, Balinese Hindus in carrying out ngayah do not see one's caste, one's social status, men and women both carry out ngayah as a form of social service which is primarily aimed at Sang Hyang Widhi Wasa.

Ngayah contains the third value of Pancasila, namely Indonesian Unity. One of the points in the third principle is being able to place unity, unity and interests and safety of the nation and the state as a common interest over personal and group interests. At present, the implementation of the third principle of Pancasila is reflected in the attitude of the Balinese Hindus who work together with other Indonesian people to carry out ngayah by providing assistance to the refugees in relation to the status of Mount Agung which is feared to erupt.

Ngayah reflects the fourth principle of Pancasila, which is a society led by wisdom in deliberation / representation. The points contained in the fourth precept of Pancasila include respecting and upholding every decision reached as a result of deliberation and in good faith and a sense of responsibility in accepting and implementing the results of the deliberation decision. The implementation of ngayah is always preceded by a meeting held by all members of the banjar to determine the implementation of ngayah, division of labor, fundraising and so on. The results of the meeting will be carried out by the Balinese Hindu community in good faith and full of responsibility. This is because the Balinese are a community of Adat Laws who are very obedient to Adat Law. Ngayah is generally related to religious and customary activities. Balinese Adat Law is a living law for Balinese Hindus, even though it is an unwritten law but Balinese Adat Law is strongly adhered to by Balinese people.

Ngayah reflects the fifth principle of Pancasila, namely social justice for all Indonesian people. One of the points of the fifth precept is to develop noble deeds, which reflect the attitude and atmosphere of kinship and mutual cooperation. The implementation of ngayah is a noble deed because at the time of carrying out all Balinese Hindus carry out it sincerely, sincerely, selflessly, without expecting any reward. The implementation of ngayah is also carried out in a family and mutual cooperation atmosphere. None of the Balinese Hindus carry out ngayah individually.

\subsection{Application of Sanctions for Balinese Hindu Communities Who Do Not Ngayah Reviewed from Balinese Adat Law and Hindu's Law}

The Balinese Hindu community lives in a set of social organizations with a cultural system that is closely related to religious values, thus, Adat Law that lives and is recognized in society is mixed with religious values. Closely linked between Adat Law and Religious Law, Van 
Vollehhoven has said that Hinduism has a strong influence on customs. Some literature on adat law all states that adat law in Bali is colored by elements of Hinduism. Hazairin argued that the island of Bali was isolated for quite a long time from outside influences, so the development of Hinduism and Buddhism was very deep and entered into adat so that it could not be separated anymore.

Soekanto also mentioned that traditional villages in Bali are territorial legal alliances in which villagers together have an obligation and together have the will to clear the village area for the purposes of religious affiliation. Life and thought and behavior patterns of Balinese Hindu society are always related to belief in Hinduism, therefore it is not exaggerating to say that Adat Law in Bali originates in the Vedas as the holy book of Hinduism. ${ }^{6}$

The Balinese Hindu community is a society that is strongly influenced by the values in Hinduism, therefore it is also in harmony with one of the principles in Hinduism. The principle is that all activities carried out by Hindus are based on sincere and sincere souls. All activities carried out by Hindus are an offering to Ista Dewata (Sang Hyang Widhi Wasa which is realized both in Nirguna Brahman and in Saguna Brahman). This principle is regulated in Bhagawadgita II.47, namely: Karmany evadhikaras te ma phalesu kadacana ma karma phala hetur bhur ma te sanggostava akarmani. (Only doing duty is not the result of that action (you think), never reward is your motive for working, do not also work (nirkarma) because it is merely narrow.

The actions of members of the Adat Law community who are not in accordance with Adat Law are illegal. These illegal acts

6 Hazairin dan Soekanto, quoted in Tjokorda Raka Dherana, Pengenalan Bahanbahan Hukum Adat Bali dalam Menunjang Pembinaan Hukum Nasional dalam Kerta Patrika Edisi Khsusu dalam Ranka Lustrum VI FH UNUD, Denpasar, P. 32. in the literature of AdatLaw are called customary offenses, adat or adat violations. ${ }^{7}$ Bushar Muhammad argued that delik adat is a one-sided act of an individual or group of individuals, threatening or offending or disturbing the balance and the life of the community is material or immaterial, to one person or to society in the form of unity. Such actions will result in an indigenous reaction. ${ }^{8}$

The element of disruption of balance in people's lives is an element of offense, in the view of Balinese Hindus, the balance that must be maintained is the balance in the tri hita karana elements. Adat violations will be subject to adat fines, in Bali generally called danda or pamidanda. One type of adat violation that is widely practiced by Balinese Hindus is not carrying out ngayah and in some villages people who do not carry out ngayah will be charged with danda.

According to Wayan Sutawa, based on the decision of Paruman Krama Adat, for members of the Balinese Hindu community who did not carry out ngayah, they were penalized in the form of a fine of $\mathrm{Rp}$. 5,000,00 (five thousand rupiahs). Every month members of the community gather and collect data on anyone who does not carry out the payment and fines are collected as the people's cash. The money will then be collected for the construction and maintenance of pura and bale banjar. ${ }^{9}$

Ida Bagus Parwatha said that in the Banjar Pekandelan, there were no monetary sanctions for community members who did not carry out ngayah. However, if the person does not carry out ngayah for 3 (three) times in a row, the person concerned must

${ }^{7}$ Wayan P. Windia, Op Cit, P. 180.

8 Bushar Muhammad, quoted in I Made Widnyana, Kapita Selekta Hukum Pidana Adat, Bandung, Eresco, 1993, P. 5.

${ }^{9}$ The results of the interview with Wayan Sutawa, traditional leader of desa Simpang Jeruk village, kecamatan Lingga, kabupaten Lampung Tengah, Lampung province. 
apologize and give reasons for his absence. This is due to more moral responsibility as a member of the banjar. ${ }^{10}$

According to Matra Kumara, in her village, for women who do not carry out ngayah are not subject to any sanctions, but people who carry out ngayah are believed to have good karma savings. For men who do not carry out ngayah, a fine of Rp. 10,000.00 (ten thousand rupiah). ${ }^{11}$ different from Ulakan village, according to Made Sutama, in the village of Ulakan, a fine of $\mathrm{Rp}$. 100,000.00 (one hundred thousand rupiah) for members of the Balinese Hindu community who do not carry out ngayah. ${ }^{12}$

The purpose of sanctions in Adat Law is to restore the balance that is disturbed due to adat law. Adat sanctions in Bali are sanctions imposed by the village of Pakraman or other adat institutions to a person or group of people and / or their families because they are considered to have violated adat norms and norms of Hinduism and are intended to restore the balance of sekala (real nature) and niskala (nature supernatural) in society.

\section{Conclusion}

1. Implementation of the Pancasila Values contained in Ngayah in the Balinese Hindu Community

The ngayah tradition carried out by Balinese Hindus is full of Pancasila values.

10 The results of an interview with Ida Bagus Parwatha, a traditional leader in Banjar Pekandelan, Desa Sanur Kaja Village, Kecataman Denpasar Selatan, Denpasar, Bali Province.

Interview with Matra Kumara, traditional leader in Desa Padangbai, Kecamatan Manggis, Kabupaten Karangasem, Bali Province.

${ }^{12}$ The results of an interview with Made Sutama, a traditional leader in Desa Ulakan, Kecamatan Manggis, kabupaten Karangasem, provinsi Bali.
2. Application of Sanctions for Balinese Hindu Communities Who Do Not Ngayah Reviewed from Balinese Adat Law and Hindu's Law

Sanctions for Balinese Hindus who do not carry out ngayah in general are fines or danda in the form of payment of a sum of money whose nominal amount depends on each Pakraman village.

\section{Reference}

Djaren Saragih, Pengantar Hukum Adat Indonesia Edisi III, Bandung : Tarsito, Bandung, 1996.

Gitananda, W. S., Cika, I. W., Suarka, I. N., \& Yasa, I. W. S. (2018). Materialization And Humanization Of The Spirit: A Contextualization Based On The Stylistic Representation Of The Balinese Hindu Modern Philosophy. Vidyottama Sanatana: International Journal of Hindu Science and Religious Studies, 2(1), 83-98.

Ronny Hanitijo Soemitro, Metodologi Penelitian Hukum dan Jurimetri, Ghalia Indonesia, Jakarta, Cetakan Kelima, 1994.

Tjokorda Raka Dherana, Pengenalan Bahanbahan Hukum Adat Bali dalam Menunjang Pembinaan Hukum Nasional dalam Kerta Patrika Edisi Khusus dalam Rangka Lustrum VI FH UNUD, Denpasar.

Tolib Setiady, Intisari Hukum Adat Indonesia - Dalam Kajian Kepustakaan, Bandung : Alfabeta, 2015.

Wayan P. Windia dan Ketut Sudantra, Pengantar Hukum Adat Bali, Denpasar : Swasta Nulus Bekerja sama dengan Bali Shanti Pusat Pelayanan Konsultasi Adat dan Budaya Bali LPPM Unud dan Puslit Hukum Adat LPPM Unud, 2016.

Widnyana, Kapita Selekta Hukum Pidana Adat, Bandung, Eresco, 1993 